\title{
MIĘDZY PODMIOTEM ABSOLUTNYM A BYTOWA NIEOKREŚLONOŚCIĄ. O ANTYHUMANISTYCZNYCH ŹRÓDŁACH WSPÓŁCZESNEJ KULTURY
}

Nowoczesny podmiot jeszcze się nie narodzit ${ }^{1}$.

Streszczenie. Artykuł jest próbą ukazania źródeł współczesnej kultury. Autor stawia w nim tezę, że u jej podstaw znajduje się dziś myślenie w gruncie rzeczy antyhumanistyczne myślenie spod znaku „śmierci człowieka”, jego bytowej nieokreśloności, ale również spod znaku nowożytnego cogito, podmiotu zabsolutyzowanego, który staje się szczególnego rodzaju fundamentem, ostatecznym podłożem rzeczywistości.

W pierwszej części autor przedstawia specyfikę nowożytnego rozumienia bytu ludzkiego, zgodnie z którą człowiek - jako podmiot myślący, poznający, samoświadomy, racjonalny - przypisuje sobie rolę nowożytnego suwerena, Demiurga, jedynego ustawodawcy i architekta nowego, prawdziwie ludzkiego świata. W ten sposób - zgodnie ze znaczeniem słowa „podmiot” - człowiek staje się „ostatecznym podłożem” rzeczywistości.

Dalej autor wykazuje, że absolutyzowanie podmiotu, przypisywanie mu coraz to większych kompetencji, doprowadza ostatecznie do jego podważenia i zanegowania. Odwołując się do koncepcji takich filozofów jak Nietzsche, Heidegger, Sartre, Foucault, Derrida twierdzi, że negacja kartezjańskiego cogito, „śmierć” pewnej określonej wizji człowieka jako podmiotu rodzi myślenie, zgodnie z którym człowiek staje się bytowo nieokreślony.

Zarówno nowoczesne jak i ponowoczesne spojrzenie zostały w pewien sposób naznaczone myśleniem antyhumanistycznym. W jednym i drugim przypadku mamy bowiem do czynienia z nierealistycznym spojrzeniem na człowieka. Autor mówi o „antyhumanizmie pana i władcy” oraz „antyhumanizmie zluzowanego” i wskazuje, że właśnie one stanowią swego rodzaju podglebie współczesnego humanizmu.

W punkcie ostatnim pokazano, że sposób rozumienia roli podmiotu na przestrzeni ostatnich kilku wieków, został zbudowany na niezwykle prostej opozycji - wszystko albo nic. Ponieważ nieprawdą jest, że podmiot jest dla siebie całkowicie racjonalny, przejrzysty, że jest autonomicznym panem samego siebie, musi zniknąć, trzeba o nim zapomnieć, stąd idea „śmierci człowieka”.

1 C. Delsol, Esejo człowieku późnej nowoczesności, tłum. z fr. M. Kowalska, Kraków 2003, 91. 
W tym kontekście, odwołując się do intuicji francuskiej profesor filozofii Chantal Delsol, autor przedstawia próbę wyjścia z aporii między nowoczesnym podmiotem absolutnym, samowystarczalnym, a ponowoczesnym podmiotem, którego właściwie nie ma. Wskazuje na konieczność realistycznego spojrzenia na człowieka, gdyż tylko na takim spojrzeniu można zbudować prawdziwie humanistyczną kulturę.

Słowa kluczowe: podmiot, człowiek jako podmiot, „śmierć człowieka”, nowożytność, ponowoczesność, antyhumanizm, Nietzsche, Heidegger, Sartre, Foucault, Derrida, Delsol, realizm

1. Człowiek nowożytny - podmiot. 2. Człowiek ponowoczesny - bytowa nieokreśloność.

3. Antyhumanizm - podglebie współczesnego humanizmu. 4. Podmiot świadomy swojej niemocy - w poszukiwaniu trzeciej drogi. 5. Zakończenie.

Jean Baudrillard w wywiadzie z 1984 roku wyraził następującą opinię: „Nie pozostało już nic do zniszczenia. To jest problem. To znaczy, przez ostatnie dwadzieścia lat wszystko zostało radośnie zniszczone, wszystko podane w wątpliwość: gospodarka, człowiek, humanizm, władza. Wszystko zostało zanalizowane. Przeprowadzono radykalną krytykę wszystkiego i poszło to bardzo dobrze, ponieważ stało się w obliczu pewnego systemu. Teraz nie ma już żadnych wrogów, wobec których można by kierować radykalną krytykę. Marksizm? Nie, to zostało zrobione. Psychoanaliza prawie tu [to znaczy we Francji] zniknęła. Władza polityczna? Cóż, istnieje ona jako pewien rodzaj symulacji, jednakże nie da się już dłużej mówić o jakimś wrogu klasowym itd. I to jest właśnie ten rzeczywisty problem. W istocie rzeczy jest to problem relatywności. Negatywność nie jest już możliwa, dokładnie dlatego, że nie istnieje już żadna pozytywność”2.

Czytając te słowa, chciałoby się powiedzieć, że jest w nich dużo przesady, że wprawdzie doświadczamy jakiegoś fundamentalnego kryzysu, egzystencjalnego braku oparcia, zagubienia, ale nie totalnego zniszczenia. Czy na pewno? Człowiek drugiej połowy XX wieku podważył przecież wszystko. W swej wszechogarniającej

2 Gra resztkami. Wywiad z Jeanem Baudrillardem przeprowadzony przez Salvatore Mele i Marka Titmarsha, tłum. z ang. A. Szachaj, w: Postmodernizm a filozofia. Wybór tekstów, red. S. Czerniak, A. Szachaj, Warszawa 1996, 224-225. 
podejrzliwości, w ponowoczesnej pasji tworzenia wszystkiego od nowa rozprawił się z Bogiem, $\mathrm{z}$ obiektywnie istniejącym i poznawanym przez nas światem, $\mathrm{z}$ filozofią, $\mathrm{z}$ historią, z prawdą... Może zatem Baudrillard wcale się nie myli? Może jego słowa bardzo dobrze oddają stan współczesnej kultury?

W świecie, w którym „nie pozostało już nic do zniszczenia”, ogłasza się więc „śmierć Boga”, ale także „śmierć człowieka”, a kwestie etyczne, kwestie dotyczące moralności, życia społecznego umieszcza w pewnym, na pierwszy rzut oka niedostrzegalnym, klimacie antyhumanizmu. Niedostrzegalnym, bo zewsząd słyszymy o prawach człowieka, o prawach jednostki, o tak bardzo pożądanych humanistycznych postawach, o humanistycznym spojrzeniu na świat. Słowo „humanizm” gości nieustannie na uniwersyteckich wykładach, w parlamentach, w mediach, podczas dyskusji polityków. Co jednak zawiera się w tym słowie? Co znajduje się u spodu współczesnego rozumienia tego, co ludzkie? $\mathrm{Na}$ czym polega ten humanistyczny, a więc „ludzki” (łac. bumanus) sposób istnienia? Kiedy spojrzymy na ten problem z takiej właśnie perspektywy, kiedy przebijemy się przez te bardzo powierzchowne humanistyczne "zaklęcia”, dostrzeżemy pewien znamienny paradoks. U podłoża współczesnej - wydawałoby się - humanistycznej kultury znajduje się myślenie w gruncie rzeczy antyhumanistyczne. To myślenie spod znaku „śmierci człowieka”, „śmierci podmiotu”, depersonalizacji, całkowitego braku „swoistości" ludzkiego bytu, ale również spod znaku nowożytnego cogito, podmiotu zabsolutyzowanego, który staje się szczególnego rodzaju fundamentem.

W niniejszym artykule - oczywiście w wielkim uproszczeniu przedstawię, jak rodziły się te dwie wizje człowieka i co je charakteryzuje. Na tle dziejów rozumienia podmiotowości ukażę ich wzajemną

3 Chantal Delsol mówi, że doktryna praw człowieka, dziś bardziej niż kiedykolwiek wcześniej, przypomina zaklinanie rzeczywistości. Zob. C. Delsol, Esej o człowieku późnej nowoczesności, tłum. z fr. M. Kowalska, Kraków 2003, 91. 
zależność, odmienność, ale jednocześnie pewne szczególne podobieństwo. Wyjaśnię, na czym polega ich antyhumanizm i dlaczego kultura, odwołująca się do takiego właśnie rozumienia, ma w gruncie rzeczy antyhumanistyczny charakter. Na koniec, przywołując Chantal Delsol, zasygnalizuję próbę wyjścia z aporii między nowoczesnym podmiotem absolutnym a ponowoczesnym - całkowicie nieokreślonym. Jeśli bowiem ta francuska profesor filozofii ma rację i nowoczesny podmiot rzeczywiście jeszcze się nie narodzi14, to nasza kultura wciąż czeka na takie rozumienie człowieka, które dostrzegać będzie jego wyjątkowość i wielkość, ale także jego ograniczoność i niewystarczalność, które bynajmniej owej wielkości nie podważają.

\section{CZłOWIEK NOWOŻYTNY - PODMIOT}

Można się spierać, czy nowożytność rodzi pewien nowy sposób rozumienia człowieka, czy może nowy sposób rozumienia człowieka rodzi nowożytność. Nie można jednak nie zgodzić się z tym, że fundamentalną cechą tożsamości nowożytnej jest rozumienie człowieka jako podmiotu. Nowożytny podmiot jest ideą, bez której nie da się zrozumieć człowieka nowożytnego, ale także człowieka współczesnego. Czym było jednak to - tak brzemienne w skutkach - „odkrycie” i na czym polegała specyfika tego całkowicie nowego sposobu rozumienia człowieka? Dlaczego tak rozumiany człowiek ostatecznie musiał „umrzeć”? Odpowiedź znajdujemy w analizie dziejów „podmiotu”, $\mathrm{w}$ historii rozumienia tego pojęcia i jego stosowania.

Początki sięgają Arystotelesa. To Stagiryta wprowadza to słowo do filozoficznego języka. Greckie to bypokeimenon wiąże z substancją, która w odróżnieniu od przypadłości istnieje jako „ostateczne podłoże”, jako „to, co leży u podstaw”, co w porównaniu ze zmiennymi formami zjawiania się bytu nie zmienia się, lecz stanowi „podłoże”,

4 Tamże, 96. 
„podstawę” zmiennych jakości5. W Księdze VII Metafizyki Arystoteles pisze: „Substancję rozumie się, jeśli nie więcej, to przynajmniej na cztery sposoby. Substancja jawi się zarówno jako to, czym coś było i jest [istota], jak też ogół i rodzaj, oraz na czwartym miejscu, podmiot. Podmiotem jest to, o czym orzeka się wszystko inne, a jego samego już więcej o niczym. I dlatego najpierw to omówić należy, gdyż wydaje się, że przede wszystkim substancją jest pierwszy podmiot. Otóż raz rozumie się tak materię, kiedy indziej formę, a jako trzecie to, co z nich złożone"6. W Księdze $V$ wyjaśnia natomiast: „substancję rozumie się zasadniczo: jest to ostateczne podłoże, którym jest to, czego nie przypisuje się już niczemu innemu, a po drugie byt jako coś konkretnego, co może być też oddzielone, to znaczy forma, czyli istota"?.

Arystoteles łączy więc podmiotowość z rzeczywistością, ze światem realnie istniejących bytów. Podmiotem jest bowiem substancja, czyli każdy istniejący byt, który jest konkretny, indywidualny, oddzielny i samoistny, to znaczy taki, który, by istnieć - inaczej niż przypadłość - nie potrzebuje żadnego innego bytu. To przedmiot, substrat bądź nośnik cech, do którego odnoszą się dotyczące go orzeczniki ${ }^{8}$. Otaczająca nas rzeczywistość w taki właśnie sposób istnieje, że składa się z konkretnych bytów, których podmiotowość jest pierwszym $z$ narzucających się - w tym miejscu chciałoby się użyć słowa „atrybutów”, „cech”. Podmiotowość jednak to nie kwestia właściwości, własności. Zgodnie z rozumieniem Arystotelesa to problem samej bytowości, charakterystycznego sposobu istnienia świata. Każda indywidualna rzecz, jeśli istnieje, istnieje właśnie jako podmiot, a to znaczy, że jest wewnętrznie tożsama, niesprzeczna,

5 Zob. H.G. Gadamer, Rozum, słowo, dzieje, tłum. z niem. M. Łukasiewicz, K. Michalski, Warszawa 2000, 109.

6 Arystoteles, Metafizyka, I, 1028b33-1029a3, tłum. z grec. T. Żeleźnik, Lublin 2000, 326.

7 Tamże, 1017b23-25, 248.

8 Zob. A. Niemczuk, Między bytem a wartością: problem podmiotu, w: Studia nad ideą podmiotowości człowieka, red. Z.J. Czarnecki, Lublin 1999, 12. 
odrębna od każdego innego bytu, mimo całej swojej zmienności jakoś przecież stała, „zamknięta”, a więc możliwa do poznania.

Powyższe znaczenie podmiotowości, wyznaczone przez greckie to hypokeimenon, przetłumaczone przez Boecjusza na łacińskie subiectum, dominowało do końca średniowiecza i było właściwie jedynym znaczeniem słowa „podmiot"9. Zgodnie z nim, podmiotem - trzeba to wyraźnie podkreślić, w takim samym bytowym sensie jak wszystkie inne byty - był także człowiek. Nie znaczy to oczywiście, że nie dostrzegano wyjątkowego charakteru człowieka. Chodzi o to, że był on rozumiany jako rodzaj bytu przedmiotowego, który nie jest naturze przeciwstawiony, lecz istnieje w niej jako konkretny byt, wprawdzie wyróżniony, jedyny w swoim rodzaju, ale istniejący obok wielu innych konkretnych bytów. Jego podmiotowość była więc rozpatrywana w kontekście filozofii ontologicznej, metafizyki, stanowiąc - jedynie i aż - jej szczególny fragment ${ }^{10}$.

Filozofia nowożytna ten sposób myślenia porzuca. WXVII wieku rozpoczyna się swego rodzaju antropocentryczny przewrót. I nie chodzi jedynie o zwykłą gloryfikację człowieka, o docenienie jego wartości i znaczenia. Chodzi o pewną istotną przemianę rozumienia podmiotowości, która stanie się szczególnego rodzaju „mitem założycielskim” nowożytności ${ }^{11}$. Kartezjusz uruchamia proces, zgodnie z którym podmiotowość nie będzie już wiązana $\mathrm{z}$ istniejącą rzeczywistością, a jedynie $\mathrm{z}$ człowiekiem. W okresie, kiedy filozofia

9 Zob. tamże, 12-13; Zob. także. T. Kitliński, Między tożsamością a różnicą: podmiot w procesie, w: Studia nad idea podmiotowości człowieka, dz. cyt., 223.

10 Zob. A. Niemczuk, Między bytem a wartością, dz. cyt., 12-13.

11 To wtedy właśnie rodzi się podmiot w dzisiejszym tego słowa znaczeniu. Po pierwsze, jako proste przeciwieństwo przedmiotu, który jest pasywnym odbiorcą różnego rodzaju podmiotowych aktywności. Mówimy więc o: „podmiocie pracy”, „podmiocie miłości”, „podmiocie poznania”, itp. Po drugie, jako swego rodzaju godności, wartości, którą należy chronić, o którą trzeba zabiegać. W tym znaczeniu: „człowiek nie może utracić swojej podmiotowości”, „człowieka zawsze należy traktować podmiotowo, a nie przedmiotowo”. W pierwszym znaczeniu podmiotowość jest oczywiście terminem aksjologicznie obojętnym. W drugim już wartościującym. Zob. A. Niemczuk, Między bytem a wartością, dz. cyt., 11. 
z metafizyki staje się teorią poznania, rzeczywistość przestaje być tą oto rzeczywistością. Staje się przedmiotem poznania, zawsze więc „rzeczywistością poznawaną”, „rzeczywistością w relacji”, w relacji do człowieka jako podmiotu poznania. Podmiotu, który od tego momentu zaczyna odgrywać rolę decydującą, pierwszoplanową. $\mathrm{Na}$ początku jedynie jako podmiot myślący, poznający, samoświadomy, ale $\mathrm{z}$ biegiem czasu jako podmiot warunkujący czy wręcz konstruujący przedmiot poznania. Racjonalność świata przestaje być bowiem kwestią realnie istniejącej rzeczywistości, a staje się kwestią poznającego podmiotu jako jej źródła. Podmiotu, który w ten sposób - by tak rzec - odbiera światu jego podmiotowość. To bardzo znamienne. W momencie, kiedy podmiotowość zostaje związana z człowiekiem, świat traci swój podmiotowy charakter. Przestaje być autonomiczny, niezależny. Autonomiczny i niezależny staje się człowiek do tego stopnia, że to on - wracając do Arystotelesowskiego to hypokeimenon - staje się owym „ostatecznym podłożem”, "podstawą" świata we wszystkich jego wymiarach.

Charles Taylor określa ten proces mianem „uwewnętrznienia” 12 . W swojej klasycznej pracy Źródta podmiotowości pisze, iż jedną z trzech najistotniejszych cech tożsamości nowoczesnej jest całkowicie nowe rozumienie wewnętrzności, czyli rozumienie człowieka jako istoty obdarzonej wewnętrzną głębią i powiązane z nią przekonanie, że jesteśmy „podmiotami” ${ }^{13}$. Ta nowa koncepcja wewnętrzności to „wewnętrzność samowystarczalna”" ${ }^{4}$, przekonana, że każdy z nas posiada - jak pisze Taylor - „władzę samodzielnego tworzenia pewności" 15 , że racjonalność to nie kwestia widzenia rzeczywistości, odwoływania się do jakiegoś obiektywnego porządku rzeczy, lecz

12 C. Taylor, Źródła podmiotowości. Narodziny tożsamości nowoczesnej, tłum. z ang. M. Gruszczyński, O. Latek, A. Lipszyc, A. Michalak, A. Rostkowska, M. Rychter, Ł. Sommer, Warszawa 2012, 270.

13 Zob. tamże, 4-5.

14 Tamże, 296.

15 Tamże, 294. 
„wewnętrzna własność myślącego podmiotu”16. Oto przemiana, jaka zachodzi między starożytnością, średniowieczem a nowożytnością. Taylor ukazuje ją na tle pogłębionych poszukiwań źródeł nowożytnej tożsamości, moralności i wskazuje na zmianę ich umiejscowienia dokonującą się właśnie poprzez Kartezjusza ${ }^{17}$. Przywołując Platona i św. Augustyna, mówi o ich przekonaniu, że źródło siły moralnej, życia zgodnego z rozumem, dzięki któremu zyskujemy panowanie nad sobą, wewnętrzny pokój, znajdują się na zewnątrz nas. To królestwo Prawdy, Dobra, Piękna czy już po chrześcijańsku - Bóg. I nawet jeśli Augustyn chce poznać jedynie własną duszę, to przecież tylko dlatego, by tam w swoim wnętrzu ostatecznie spotkać Tego, który jest bliżej niego niż on sam. Ponieważ prawda, której szuka rzeczywiście wewnątrz siebie, ostatecznie znajduje się poza nim, to znaczy w Bogu.

Kartezjusz - zdaniem Taylora - uruchamia proces całkowicie przeciwny. Wszystko zostaje umieszczone wewnątrz nas. Taylor pisze: „Uwewnętrznienie w pisane w epokę nowożytną, sformułowane w sposób najdonioślejszy i najsilniej oddziałujący przez Kartezjusza, różni się bardzo od wewnętrzności Augustyńskiej. Umieszcza ono, w bardzo dosłownym sensie, źródła moralne wewnątrz nas. Przemiana w stosunku do Platona i Augustyna polega tu na tym, że nie postrzegamy już siebie jako powiązanych ze źródłami moralnymi na zewnątrz nas, a przynajmniej nie w ten sam sposób. Pewna ważna władza została uwewnętrzniona"18.

Ten mechanizm dotyczy źródeł moralnych, ale także samej racjonalności. Nieco dalej Taylor dodaje: „Racjonalność nie polega już na widzeniu rzeczywistości, lecz jest wewnętrzną własnością myślącego podmiotu. Przeprowadzając tę zmianę, Kartezjusz sformułował pogląd, który stał się standardowym podejściem nowożytnym"19.

16 Tamże, 293.

17 Zob. szerzej: tamże, 219-296.

18 Tamże, 270.

19 Tamże, 293. 
W ramach takiego „standardowego nowożytnego podejścia” świat zewnętrzny - jak słusznie zauważa Taylor - zostaje więc „uwewnętrzniony". Przedmiot, jako korelat aktów świadomości, staje się $\mathrm{w}$ coraz większym sensie związany z podmiotem, warunkowany przez podmiot. I choć u Kartezjusza idee wciąż reprezentują rzeczy, które znajdują się poza re cogitante, a u Kanta doświadczenie świata zewnętrznego wciąż ma istotne znaczenie, to już u Hegla wszelkie struktury przedmiotowe zostają zredukowane do przejawów obecności Ducha jako prawdziwej i jedynej substancji, a zarazem ostatecznego podmiotu dziejów, podmiotu jako bytu absolutnego ${ }^{20}$. To bowiem, co naprawdę istnieje, to podmiot i tylko podmiot ${ }^{21}$. Podmiot, który w istocie jest poznającą i działającą subiektywnością, samowiedzą, samorefleksją, dla której to, co zewnętrzne, przestaje mieć jakiekolwiek znaczenie. Co więcej, by zostać zrozumiane, musi być wchłonięte przez podmiot, ponieważ może być sobą tylko w podmiocie ${ }^{22}$.

Ta racjonalistyczna tradycja, której początki znajdujemy u Kartezjusza, w takim właśnie kierunku (Kartezjusz zapewne nie mógł tego przewidzieć) ewoluuje. Podmiot myślący, rozumny, wolny staje się ostatecznie podmiotem absolutnym, w którym zachodzi parmenidejska tożsamość bytu i myśli. Świat zewnętrzny, którego istnienia trzeba wprawdzie w koncepcji kartezjańskiej dowodzić (pewne jest przecież istnienie jedynie cogito), w idealizmie niemieckim, ale także fenomenologii Husserla zostaje zredukowany do procesów wewnątrzpodmiotowych. Podmiot staje się „miejscem”, w którym zachodzi już nie tylko poznawanie świata, lecz jego egzystowanie. Hegel pisze: „Dlatego to, co zewnętrzne, jest, po pierwsze, tą samą treścią co to, co wewnętrzne. (...) to, co wewnętrzne, i to, co zewnętrzne, są same

20 Zob. Powszechna Encyklopedia Filozofii, t. IX, Lublin 2008, 249-251.

21 Zob. Ś.F. Nowicki, Filozofia Hegla jako spekulatywny system, w: G.W.F. Hegel, Encyklopedia nauk filozoficznych, tłum. z niem. Ś.F. Nowicki, Warszawa 2014, XXXI.

22 A.W. Nowak, Podmiot, system, nowoczesność, Poznań 2011, 31-32. 
w sobie i dla siebie tożsame, a ich różnica określana jest jako tylko założoność. Tą tożsamością jest rzeczywistość"23.

Świat „egzystuje” zatem w świadomości. Staje się czymś mniemanym przez specyficzne akty świadomości i właściwie tylko tym ${ }^{24}$. Człowiek jako subiectum staje się absolutnym punktem odniesienia. Jako świadomość - absolutnym źródłem wiedzy, a jako zasadnicza i bezwzględna wartość - absolutnym źródłem wszelkich praw i wartości ${ }^{25}$. Vincent Descombes w książce To samo i inne traktującej o filozofii francuskiej w latach 1933-1978 pisze: „W tym, co zwykło się określać »filozofią świadomości«, to znaczy w tradycji kartezjańskiej, »myślę, więc jestem« jest jednocześnie źródłem i regułą wszelkiej prawdy. Jest to pierwsza prawda, jest to prawda będąca zasadą wszystkich innych prawd i jest to w końcu wzór prawdy. Ego zawarte $\mathrm{w}$ ego cogito, ego sum, jest absolutem, wobec którego wszystko inne jest relatywne: jego prawda, która nie zależy od żadnej innej, warunkuje wszystkie inne"26. To bardzo trafne stwierdzenia. Rzeczywistość traci swą siłę, a siły nabiera człowiek, właśnie jako podmiot. Wszystko staje się zależne od niego, przez niego warunkowane. W ten sposób „świadek” istniejącej rzeczywistości przeobraża się w jej „twórcę”, „konstruktora”, „prawodawcę”. Staje się panem. Już nie tylko - o co zabiegali starożytni Grecy - panem samego siebie, ale panem i władcą świata ${ }^{27}$. Alain Renaut w książce Era jednostki. Przyczynek do historii podmiotorwości pisze o tym w następujący sposób: „nowożytnym jest

23 G.W.F. Hegel, Encyklopedia nauk filozoficznych, dz. cyt., 183-185.

24 Zob. K. Gloy, Wprowadzenie do filozofii świadomości. Problematyka i historia zagadnienia świadomości oraz samoświadomości, tłum. z niem. T, Kubalica, Kraków 2009, 62-63.

25 Zob. B. Banasiak I cóż po podmiocie w tak jałowym czasie? Przyczynek do krytyki kategorii podmiotu, Forum Oświatowe 20(2008), http://forumoswiatowe.pl/index.php/ czasopismo/article/view/248/163 (dostęp: 8.07.2017), 28.

26 V. Descombes, To samo i inne. Czterdzieści pięć lat filozofii francuskiej (1933-1978), tłum. z fr. B. Banasiak, K. Matuszewski, Warszawa 1997, 29-30.

27 Szerzej na temat rozumienia podmiotowości u Greków: zob. Z.J. Czarnecki, Idea podmiotowości człowieka w myśli antycznej, w: Studia nad ideą podmiotowości człowieka, dz. cyt., 43-62. 
taki stosunek do świata, w którym człowiek nadaje sobie władzę stanowienia (swych działań i przedstawień, historii, prawdy, prawa): owa władza stanowienia definiuje podmiotowość w tym sensie, iż pojawienie się człowieka jako podmiotu oznacza jego pozycję jako subiectum, pewnego "pod-łoża«, na bazie którego wszystko musi się odtąd wspierać" 28 .

W tym miejscu dochodzimy do jeszcze jednego niezwykle istotnego aspektu „nowożytnego stosunku do świata”, tego szczególnego rozumienia nowożytnej podmiotowości. Mam na myśli pewien rodzaj „władztwa” i - co się z tym wiąże - niekwestionowalnej autonomii, działania zgodnego jedynie $\mathrm{z}$ własnym rozumem. Człowiek jako podmiot myślący, poznający, samoświadomy, racjonalny, jako „ostateczne podłoże” wszelkich zjawisk przypisuje sobie rolę nowożytnego suwerena, Demiurga, jedynego ustawodawcy i architekta nowego, prawdziwie ludzkiego świata. Tę rolę szczególnie mocno eksponuje oświecenie, dla którego ludzki rozum i wolność stają się nie tylko centralnymi ideami, ale - jak pisze Ernst Cassirer w swojej Filozofi oświecenia - tym, „za czym wiek ów tęskni i do czego dąży, czego pragnie i czego dokonuje" 29 . Zgodnie $\mathrm{z}$ takim rozumieniem $\mathrm{w}$ centrum staje podmiot $\mathrm{w}$ pełni przejrzysty dla samego siebie, świadomy, samodzielny w poznaniu, ale także wolny i całkowicie niezależny w działaniu. Oto prawdziwy oświeceniowy bohater. Kant w swoim słynnym tekście z 1784 roku pisze o wyjściu człowieka z niedojrzałości, czyli - mówiąc inaczej - o wejściu w dojrzałość: „Oświecenie to wyjście człowieka $\mathrm{z}$ zawinionej przez niego niedojrzałości. Niedojrzałość jest nieumiejętnością w posługiwaniu się własnym rozumem bez przewodnictwa innych. Niedojrzałość ta jest zawiniona przez człowieka, jeśli jej powód tkwi nie w braku rozumu, ale zdecydowania i odwagi, by swym rozumem posługiwać

28 A. Renaut, Era jednostki. Przyczynek do historii podmiotowości, tłum. D. Leszczyński, Wrocław - Warszawa - Kraków 2001, 31-32.

29 E. Cassirer, Filozofia oświecenia, tłum. z niem. T. Zatorski, Warszawa 2010, 4. 
się bez zwierzchnictwa innych. Sapere aude! - Odważ się posługiwać własnym rozumem! - stanowi maksymę przewodnią oświecenia" 30 . I nieco dalej dodaje: „Dla oświecenia nie potrzeba niczego oprócz wolności. Co więcej, [wolności] najbardziej nieszkodliwej ze wszystkiego, co tylko można nazwać wolnością, mianowicie wolności, by czynić ze swego rozumu publiczny użytek w każdej sytuacji”"31.

Prawdziwie dojrzały człowiek (w oświeceniowym rozumieniu) to zatem człowiek, który „odważnie posługuje się własnym rozumem”, który odrzucił „gnuśność i tchórzliwość”32, który „nie potrzebuje niczego oprócz wolności", który w każdej sytuacji działa i postępuje, nie oglądając się na jakiekolwiek „zwierzchnictwa”, oprócz zwierzchnictwa własnego rozumu. To podmiot swoich własnych działań, „ostateczne podłoże”, także w znaczeniu samowystarczalności i autonomii. Autonomii, która jest posłuszeństwem swojemu własnemu prawu. Prawu, które nie jest prawem obcym, lecz prawem swojego własnego rozumu ${ }^{33}$. Taki człowiek to pan i władca świata, ufający wyjąt kowej mocy rozumu i woli, by ten rozum urzeczywistnić. To człowiek wolny od jakichkolwiek autorytetów i wiary, oprócz wiary w postęp. Wiary, że zautonomizowany i samowystarczalny rozum, jako jedyna i ostateczna instancja, doprowadzi go do prawdziwej szczęśliwości i autentycznego wyzwolenia.

\section{CZŁOWIEK PONOWOCZESNY - BYTOWA NIEOKREŚLONOŚĆ}

Nowożytne nadzieje zbudowane na takim pojmowaniu podmiotu okazały się jednak naiwne i złudne. Dość szybko dostrzeżono, że przedstawione powyżej rozumienie człowieka jest zdecydowanie

30 I. Kant, Rozprawy z filozofii historii, tłum. z niem. Translatorium filozofii niemieckiej Instytutu Filozofii Uniwersytetu im. Mikołaja Kopernika pod kierunkiem M. Żelaznego w składzie: T. Kupiś, D. Pakalski, A. Grzeliński, M. Żelazny, Kęty 2005, 44.

31 Tamże, 45.

32 Tamże, 44.

33 Zob. M. Siemek, Wykłady z filozofii nowoczesności, Warszawa 2012, 270. 
przeszacowane, a wyrosłe na nim „kult rozumu” i „kult nauki” ostatecznie nie dostarczyły wiedzy pewnej i niepodważalnej. Nie zagwarantowały tak upragnionej wolności. Nie stały się przewidywanym lekarstwem na wszelkiego rodzaju nierówności i niesprawiedliwości. A jeśli tak, trzeba było podważyć i zanegować tak rozumianą koncepcję ludzkiego bytu. O tym rodzaju wolności i samowystarczalności trzeba było szybko zapomnieć i odwołać się do jeszcze innego niż podmiotowy sposób samostanowienia.

Odnajdujemy go w ponowoczesnej idei „śmierci człowieka” jako swego rodzaju odpowiedzi na kryzys humanistycznych wartości wywołany - zdaniem rzeczników tej idei - przyjęciem jednej, konkretnej wykładni człowieka jako racjonalnego i świadomego podmiotu. Takie rozumienie musiało więc zostać porzucone. Po pierwsze dlatego, że zostało zbudowane na błędnych założeniach, co tak dobitnie ukazali „mistrzowie podejrzeń”. Po drugie, co nader wyraźnie ukazał wiek XX, zrodziło bardzo „niehumanistyczne” owoce. A po trzecie i najważniejsze, przyjęcie jednej określonej wykładni człowieka nie ma nic wspólnego z prawdziwym humanizmem, z prawdziwymi humanistycznymi wartościami. Aby wolność, suwerenność, autonomia (poznawacza i moralna) zatriumfowały, trzeba wyrzec się myślenia, które określa, definiuje, rozstrzyga. Takie myślenie ma charakter opresyjny, przemocowy i totalitarny. Na takie myślenie - po tym, co wydarzyło się w pierwszej połowie dwudziestego stulecia - po prostu nie ma już miejsca. Wizja nowożytnego podmiotu jako w pełni świadomego i odpowiedzialnego autora swych myśli i czynów to niebezpieczna iluzja, z którą należy się pożegnać, o której trzeba szybko zapomnieć.

Katarzyna Gurczyńska-Sady w swoich niezwykle intersujących analizach dotyczących podmiotu i jego dwudziestowiecznej destrukcji bardzo trafnie ujmuje istotę rodzącej się w ten sposób nowej wizji człowieka. W pracy Cztowiek jako stowo i ciato. W poszukiwaniu nowej koncepcji podmiotu pisze: „Tak jak istnienie wnętrza immanencji uznać należy za konstytutywne dla podmiotowości kartezjańskiej, 
tak w bytowej nieokreśloności trzeba dostrzec pierwszy charakterystyczny rys nowej koncepcji podmiotu" ${ }^{34}$. Rzeczywiście, negacja kartezjańskiego cogito, „śmierć” pewnej określonej wizji człowieka jako podmiotu, rodzi myślenie, zgodnie z którym człowiek staje się „bytowo nieokreślony”. Staje się bytem czystym, możliwym, niedefiniowalnym, w pewien sposób naznaczonym nicością. Nowożytna pewność zostaje wyparta przez zwątpienie, niepewność, niewyraźność. Postmodernistyczna „kultura wyczerpania” leczy bowiem nasze rozumienie człowieka $\mathrm{z}$ wszelkiej definitywności, uniwersalności, z myślenia w kategoriach prawdy, istoty, rzekomo wspólnej wszystkim ludziom racjonalnej natury.

Jak przekonuje Fryderyk Nietzsche, to wszystko to jedynie wyraz naszej wiary, „wiary w gramatykę, w podmiot językowy” ${ }^{35}$, wiary, „że "ja« jest przyczyną myśli” " ${ }^{36}$. To uleganie niczym nieuzasadnionemu przekonaniu o istnieniu jakichś duchowych przyczyn, poddania się metafizycznym złudzeniom na temat świata, jego poznawania i samego człowieka. Jeśli świat jest chaosem, jeśli się nieustannie staje, jeśli nigdy „nie jest pewnym stanem rzeczy” 37 , to nie sposób go poznać. Można go jedynie zinterpretować. Człowiek interpretuje więc świat i w ten sposób nadaje mu sens, ale również, co niezwykle istotne, nadaje sens samemu sobie. Jest bowiem, podobnie jak świat, pusty, bez sensu i dopiero w interpretacji niejako sam siebie stwarza, nadaje sens swojej własnej egzystencji.

Nie można zatem człowieka zdefiniować. Nie można go w jeden definitywny sposób określić. Jego istota bowiem - jak twierdzi inny

34 K. Gurczyńska-Sady, Człowiek jako słowo i ciało. W poszukiwaniu nowej koncepcji podmiotu, Kraków 2013, 25.

35 F. Nietzsche, Pisma pozostałe, tłum. z niem. B. Baran, Kraków 2004, 356.

36 F. Nietzsche, Zmierzch bożyszczy, czyli jak filozofuje się młotem, tłum. z niem. P. Pieniążek, Kraków 2005, 35.

37 F. Nietzsche, Pisma pozostałe, dz. cyt., 365. 
niemiecki filozof - „spoczywa w ek-sistencji”38. A to oznacza, że człowiek zawsze się „wydarza”, „istoczy”. Zawsze „stoi-poza-sobą”39. Będąc nieustannie zwróconym w stronę bycia, co Heidegger określa słynnym Dasein, nie może być opisywany w kategoriach metafizycznych, w kategoriach raz na zawsze ustanowionego i stale obecnego bytu. Człowiek „ek-sistuje”, a więc nieustannie „wykracza ku prawdzie bycia" ${ }^{40}$, a w związku z tym, nie może być sobą inaczej, jak tylko wychodząc poza siebie. Człowiek bowiem nigdy nie jest sobą $\mathrm{w}$ sobie ${ }^{41}$. W pewien sposób, podobnie zresztą jak samo bycie, jest „bezimienny"42.

Jean Paul Sartre tę „bytową nieokreśloność” ukazuje w jeszcze bardziej radykalny sposób. Autor Bytu i nicości podkreśla, że człowiek jako „byt-dla-siebie” jest przede wszystkim świadomością, a więc „bytem, który nie jest tym, czym jest, i jest tym, czym nie jest”33. Człowiek, jak pisze, jest wobec tego „przede wszystkim swą własną nicością”44, „brakiem tożsamości z samym sobą" ${ }^{45}$. Jest „naznaczony niebytem”46. To jednak bardzo specyficzny rodzaj „niebytu”. Człowiek bowiem - jak pisze Sartre w Egzystencjalizm jest humanizmem jest „pierwotnie niczym” ${ }^{47}$ i jednocześnie „tym, czym siebie uczyni” 48. Jego „nicość” to zatem możliwość uczynienia siebie niejako od nowa,

38 M. Heidegger, List o humanizmie, tłum. z niem. J. Tischner, w: tenże, Budować, mieszkać, myśleć. Eseje wybrane, tłum. K. Michalski, K. Pomian, M.J Siemek, J. Tischner, K. Wolicki, Warszawa 1977, 107.

39 Tamże, 89.

40 Tamże, 89.

41 Zob. A. de Waelhens, Heidegger i problem podmiotu, tłum. z fr. M. Kowalska, w: Heidegger dzisiaj, Aletheia 1(1991)4, 182.

42 M. Heidegger, List o humanizmie, dz. cyt., 82.

43 J.P. Sartre, Byt i nicość. Zarys ontologii fenomenologicznej, tłum. z fr. J. Kiełbasa, P. Mróz, A. Abramciów, R. Ryziński, P. Małochleb, Kraków 2007, 122.

44 Tamże, 133.

45 Tamże, 142.

46 Tamże, 56.

47 J.P. Sartre, Egzystencjalizm jest humanizmem, tłum. z fr. J. Krajewski, Warszawa 1998, 27. 48 Tamże. 
zaprojektowania siebie. Ponieważ nie ma ludzkiej natury, bo nie ma Boga, który by ją w umyśle swym począł, człowiek może być takim, jakim chce być, jakim się sam uczyni ${ }^{49}$. Ten „byt-dla-siebie” jest w takim razie oprócz świadomości także wolnością i to wolnością rozumianą jako wszechmocna władza arbitralnego decydowania ${ }^{50}$. To wolność absolutna, wolna od jakichkolwiek determinacji. Wolność, która oznacza, że nie jesteśmy związani z żadną określoną postacią siebie ${ }^{51}$. To wolność egzystencji, która poprzedza esencję. Człowiek jest bytem zawsze nieurzeczywistnionym, niegotowym, niedokonanym. Bytem nieokreślonym, by samemu się dopiero określić, zdefiniować, zaprojektować.

W przypadku jeszcze innego - najbardziej kojarzonego z ideą „śmierci człowieka” - francuskiego filozofa także nie można mówić o jakiejś trwałej naturze człowieka, racjonalnym i autonomicznym podmiocie. Dla Michela Foucaulta człowiek to jedynie wytwór konkretnej episteme, pewnego charakterystycznego dla danej epoki sposobu myślenia ${ }^{52}$. Człowiek jest całkowicie od niego zależny. Do tego stopnia, że wraz w końcem danej epoki, jako „osobliwa figura wiedzy”53, „znika”. To nie człowiek bowiem tworzy wiedzę, ale - by tak rzec - wiedza tworzy człowieka. To jednak nie wszystko. Tym, co stwarza jednostkę, jest także bezosobowa władza. Dopiero zatem perspektywa historii idei, pojąć, praktyk językowych, władzy i wiedzy, poprzez które Foucault patrzy na człowieka, pozwala odkryć „prawdę" człowieka. A ta każe widzieć w nim jedynie wytwór konstytuujących go struktur, oddziałujących na niego sił. Podmiotowość nie jest więc kwestią racjonalnego poznania, obiektywnego odczytania człowieka, lecz jego „ujarzmienia”. To struktury „władzy i wiedzy”,

49 Zob. tamże.

50 Zob. A. de Waelhens, Heidegger i problem podmiotu, dz. cyt., 186-187.

51 Zob. szerzej: K. Gurczyńska-Sady, Człowiek jako słowo i ciało, dz. cyt., 46-51.

52 Foucault wskazuje na trzy takie epoki: renesans, klasycyzm i nowoczesność.

53 M. Foucault., Słowa i rzeczy. Archeologia nauk humanistycznych, tłum. z fr. T. Komendant, Gdańsk 2006, 13. 
społeczne praktyki, normy, różnego rodzaju działania dyscyplinujące stoją u podstaw naszego ,ja”. Człowiek jest z nich „utkany”. Nie ma więc żadnej źródłowej tożsamości. Nie ma stałego, trwałego, świadomego i autonomicznego podmiotu. Są jedynie struktury, siły, dyskursy, które go w pewien sposób wytwarzają, konstytuują. Człowiek jest „utkany” z różnego rodzaju sił, struktur dyskursów, do tego stopnia, że właściwie tylko one istnieją.

Nasze myślenie o człowieku trzeba wobec tego oczyścić z wszelkich dotychczasowych klasycznych kategorii - z tego wszystkiego, co Jacques Derrida określa mianem „metafizyki obecności”. To ona kazała wierzyć w źródłową obecność jakiegoś fundamentu, zasady, centrum. Autor Struktury, znaku i gry w dyskursie nauk humanistycznych pisze: „imię człowieka jest imieniem owej istoty, która poprzez dzieje metafizyki czy onto-teologii, czyli całej swej historii, śniła o czystej obecności, o dającej pewność podstawie, o źródle i zakończeniu gry" 54 .

Według Derridy z tego typu iluzjami trzeba się definitywnie pożegnać i wprost przeciwnie, „nie oglądając się na źródło, potwierdzać grę i starać się wyjść poza człowieka i poza humanizm" 55 . Niestety w myśleniu o człowieku filozofia, jak przekonuje ten francuski dekonstrukcjonista, nigdy nie opuściła metafizycznego terytorium i dlatego nowożytny humanizm zamiast człowieka wyzwolić i obronić jego godność, w konsekwencji doprowadził do jego zniewolenia, do przemocy, która wiązała się określoną humanistyczną wykładnią ludzkiego życia ${ }^{56} . Z$ tego powodu w rozprawie zatytułowanej Kres cztowieka Derrida proponuje „absolutne zerwanie i absolutna różnicę" ${ }^{7}$. Mówi o procedurze, która wiąże się z „decyzją o zmianie

54 J. Derrida, Struktura, znak i gra w dyskursie nauk humanistycznych, w: tenże, Pismo i różnica, tłum. z fr. K. Kłosiński, Warszawa 2004, 504.

55 Tamże.

56 Zob. W. Lorenc, Hegel i Derrida. Filozofia w wersji radykalnej, Warszawa 1994, 226.

57 J. Derrida, Kres człowieka, tłum. z fr. P. Pieniążek, w: tenże, Marginesy filozofii, tłum. z fr. A Dziadek, J. Margański, P. Pieniążek, Warszawa 2002, 181. Co ciekawe jeden z fragmentów 
terenu” ${ }^{58}$, która oznacza, że „należy mówić wieloma językami i tworzyć kilka tekstów naraz”59. Mówi o „zluzowaniu człowieka”60, o „aktywnym zapomnieniu" na wzór nietzscheańskiego nadczłowieka, który - jak pisze Derrida - „pali swój tekst i zaciera ślady swoich stóp"61. Tak rozumiany człowiek nie pyta więc o istotę, naturę, cel, spełnienie, o prawdę ludzkiego bytu. Tego typu pytania byłyby bowiem „metafizycznym powtórzeniem humanizmu”62 czy - mówiąc tytułem tekstu Derridy - jego „końcem”63. Derridiańskie „zluzowanie" to wyjście poza tego typu pytania. To zapomnienie, podważenie wszelkich dotychczasowych sposobów opisywania, pojmowania, definiowania człowieka. To promowanie spontanicznych, wolnych od jakichkolwiek uzasadnień, zawsze przygodnych, często wewnętrznie sprzecznych i poróżnionych sposobów jego rozumienia. To uczynie-

tego tekstu został opatrzony bardzo wymownym tytułem Humanizm lub metafizyka. Zob. tamże, 155 .

58 Tamże, 181.

59 Tamże.

60 Derrida pisze: „Aufhebung to zluzować w tym znaczeniu, w jakim »zluzować« oznacza zarazem zwolnić, wynieść, zastąpić i promować jednym i tym samym posunięciem. Świadomość stanowi Aufhebung duszy bądź człowieka, fenomenologia jest »zluzowaniem《 antropologii. Nie już, lecz jeszcze jest nauką o człowieku. W tym sensie wszystkie opisane przez fenomenologię struktury ducha - jak i wszystko, co je nakłada na Logikę - są strukturami tego, co zluzowało człowieka. Człowiek pozostaje w nich jako swój relief. Jego istota tkwi w Fenomenologii. To dwuznaczne odniesienie zluzowania oznacza niewątpliwie kres człowieka, człowieka przeszłego, zarazem jednak spełnienie się człowieka, przyswojenie sobie jego istoty. Jest to kres człowieka skończonego". J. Derrida, Kres człowieka, dz. cyt., 163.

61 Tamże, 182.

62 Tamże.

63 Jak wyjaśnia Paweł Pieniążek, tłumacz tekstu Derridy, francuskie la fin użyte w tytule to jednocześnie kres, koniec jak i cel (uwaga tłumacza, w: tamże, 151). Pieniążek pisze: „W niniejszym przekładzie słowo to występujące w tekście Derridy w obu swych znaczeniach tłumaczymy jako kres. Taki przekład uzasadnia naszym zdaniem sens, jaki nadaje mu Derrida: spełnienie się celu człowieka, jakim jest w zachodniej - krytykowanej przez Derridę - metafizyce urzeczywistnienie się jego uniwersalnej istoty, oznacza ostatecznie kres człowieka - zniknięcie człowieka w ogólności sensu bytu, ducha lub prawdy bycia". Tamże. 
nie człowieka niedefiniowalnym, nierozstrzygalnym. To pozbawienie go jego (rzekomo w nim obecnej) swoistości.

\section{ANTYHUMANIZM - PODGLEBIE WSPÓŁCZESNEGO HUMANIZMU}

Alain Renaut w książce Era jednostki. Przyczynek do historii podmiotowości tak rozumianą krytykę idei podmiotu bardzo trafnie określa mianem „wyroku”, który dostarczył najbardziej wyraźnego motywu przewodniego większości prądów myśli współczesnej ${ }^{64}$. Rzeczywiście, bez niego trudno zrozumieć dzisiejszego człowieka, ale także wspólczesną kulturę, która wciąż pozostaje pod przemożnym jego wpływem. W ten sposób, choć mieni się humanistyczną, czerpie z koncepcji, które w istocie cechuje antyhumanizm. Antyhumanistyczny charakter ma bowiem ów „wyrok”, ale w jakimś sensie także myślenie, które bezpośrednio go poprzedziło. Renaut pisze: „Określenie mianem antyhumanizmu tego zamiaru obalenia podmiotu samo w sobie nie powinno dziwić, albowiem prawdą jest, iż od początku czasów nowożytnych humanizm polegał na tym, by waloryzować w człowieku podwójną zdolność do bycia świadomym samego siebie (autorefleksja) i ustanawiania własnego przeznaczenia (wolność jako samostanowienie), a więc dwa wymiary, które definiowały klasyczną ideę podmiotowości pojmowaną jako oznaczenie możliwości - w której mieści się człowieczeństwo człowieka - bycia świadomym i odpowiedzialnym autorem swych myśli i czynów, krótko mówiąc: swego fundamentu, swego subiectum"65.

Trudno się z tym nie zgodzić. W tym „zamiarze obalenia podmiotu”, w tym odwróceniu się - w myśleniu o człowieku - od

64 Alain Renaut pisze o tym w przedmowie (w której odnosi się także do swoich poprzednich prac) do książki Era jednostki. Przyczynek do historii podmiotowości, w której w niezwykle interesujący sposób ukazuje historię tego procesu, jako przejście od „ery podmiotu” do „ery jednostki”, jako przejście od humanizmu do indywidualizmu. Zob. A. Renaut, Era jednostki, dz. cyt., 17.

65 Tamże. 
kartezjańskiego „wzorca z Sèvres” rzeczywiście jest jakiś antyhumanistyczny rys. Czy podważenie najbardziej ludzkich zdolności autorefleksji i samostanowienia, zwątpienie w możliwość komunikacji człowieka $\mathrm{z}$ samym sobą, $\mathrm{z}$ innymi, ze światem zewnętrznym, nie ma takiego właśnie charakteru'66? Czy myślenie, wedle którego człowiek jest nieokreślony, niezdefiniowany i w jakimś sensie sam dla siebie niezrozumiały, można nazwać prawdziwie humanistycznym? Czy - nawiązując do tytułu powieści Roberta Musila z początku XX wieku - „człowiek bez właściwości” ma być tym postmodernistycznym „nowym”, „innym”, na które ludzkość całe wieki czekała? Jeśli tak, to - przywołując słowa Heideggera z jego Listu o bumanizmie - próby „wyniesienia humanitas człowieka prawdziwie wysoko”67 okazały się całkowicie kontrproduktywne. Skutkują bowiem uczynieniem człowieka „pustym”, nieokreślonym, bez żadnego „uposażenia”, bez żadnej stale obecnej, określonej natury. Skutkują więc - wbrew założeniom i głoszonym deklaracjom - myśleniem w gruncie rzeczy antyhumanistycznym. Czy podobnie nie było jednak wtedy, gdy nowożytny podmiot stawał się absolutnym punktem odniesienia, panem i władcą świata? Czy niczym nieograniczone waloryzowanie autorefleksji i samostanowienia nie było w rzeczywistości myśleniem antyhumanistycznym? Jeśli spojrzymy na ten problem właśnie z takiej perspektywy, to okaże się, że podglebie współczesnego humanizmu ma tak naprawdę antyhumanistyczną naturę. $\mathrm{Na}$ czym jednak ten antyhumanizm miałby polegać?

Problem nie jest bynajmniej tak jasny i oczywisty, jak mogłoby się wydawać, zwłaszcza że pojawia się już w momencie, kiedy chcemy zdefiniować samo pojęcie humanizmu. Już na tym etapie jawi się

66 Szerzej na temat humanizmu i antyhumanizmu w aspekcie komunikacji: Zob. A. Miś, O genezie współczesnego humanizmu, w: Derridiana, red. B. Banasiak, Kraków 1994, 21-56. Zob. A. Miś, Filozofia Współczesna. Główne nurty, Warszawa 2002, 221-226.

67 M. Heidegger, List o humanizmie, dz. cyt., 92-93. 
bardzo wiele znaczeń i sensów ${ }^{68}$. Ich wspólna cecha to jednak zgodnie ze znaczeniem łacińskiego bumanus - postawienie w centrum tego, co ludzkie, postawienie w centrum człowieka. To uznanie jego bytowej swoistości i przysługującej mu godności. To przekonanie, że człowiek zawsze winien być traktowany jako cel, a nigdy jako środek do celu, że jego dobru i szczęściu wszystko powinno zostać podporządkowane. To jednak nie koniec. Humanizmu nie można sprowadzić jedynie do pewnej postawy afirmującej człowieka, takiego czy innego nim zainteresowania lub takiej, a nie innej koncepcji etycznej. Humanizm to także, a może przede wszystkim, kwestia określonego sposobu rozumienia człowieka, pytania o jego status bytowy, jego ludzkie uposażenie i jego naturę. To problem istoty naszego człowieczeństwa i sensu ludzkiej egzystencji. Czy z takiego właśnie punktu widzenia ponowoczesne, ale również nowoczesne rozumienie człowieka nie ma antyhumanistycznego charakteru? W jednym i drugim przypadku mamy przecież do czynienia $z$ nierealistycznym jego odczytaniem.

Obie epoki wyraźnie podkreślają autonomię człowieka, jego niezależność. W obu dominuje przekonanie, że tym, co najbardziej go wyraża, jest jego wolność i suwerenność. W nowoczesności jednak takie myślenie zostało zbudowane na przeświadczeniu, że człowiek taki właśnie jest - racjonalny, autonomiczny, wolny, samoświadomy. Ponieważ ponowoczesność wie, że jest inaczej, a człowiek jest raczej wynikiem pewnych procesów, przemian i w gruncie rzeczy jest nieokreślony - autonomia, wolność, projektowanie siebie stają się

68 Mamy więc humanistyczną epokę jaką był renesans, humanistyczną literaturę, wielkich przedstawicieli humanizmu. Mówimy także o pewnej życiowej postawie, światopoglądzie, który cechuje racjonalne, naturalistyczne i antropocentryczne myślenie, zgodnie z którym człowiek nie potrzebuje żądnych innych autorytetów poza sobą, żadnych objawionych prawd. Mamy jednak także humanizm chrześcijański, który z myślenia o człowieku tej „Objawionej Mądrości” bynajmniej nie wyklucza, a wręcz przeciwnie ostateczną podstawę ludzkiej godności upatruje w Bogu. Mówimy w końcu o tak bardzo pożądanych humanistycznych wartościach, takich jak wolność, podmiotowość, autonomia, samorealizacja. 
czymś wręcz niezbędnym, nieodzownym, koniecznym. Abstrakcyjne stosunki, od których zależy, nakazują jednostce autonomiczne działanie. Jej autonomia nie jest więc czymś, co wynika z takiego, a nie innego ukonstytuowania człowieka. Przeciwnie, jest koniecznością, absolutnym - w imię obrony humanizmu, prawdziwie ludzkiego życia - wymogiem. W nowoczesności „ostatecznym podłożem”, jedynym kryterium prawdy i fałszu, dobra i zła, źródłem wartości był człowiek rozumiany jako podmiot. Było tak dlatego, że taka jest właśnie jego „moc”, takie jest jego - by tak rzec - „uposażenie”. W ponowoczesności jest podobnie, lecz wyłącznie dlatego, że nic innego mu nie pozostaje. Żadnego bowiem „uposażenia” nie ma. A jeśli tak, człowiek musi siebie nieustannie określać, tworzyć. Jego kryterium prawdy i fałszu to zatem już nie pewien obiektywny stan rzeczy, jego istota, lecz swego rodzaju najbardziej ludzkie „powołanie”. „Powołanie” zbudowane na nieokreśloności człowieka, jego nierozstrzygalności i braku „swoistości”. Nowożytność przypisała człowiekowi „moc”, której w rzeczywistości nie posiada. Ponowożytność tę „moc” podważając, uczyniła go kimś jedynie możliwym, niedefiniowalnym, „zluzowanym”, znikającym w sieci różnego rodzaju dyskursów. Czy tego typu myślenia nie mają w istocie antyhumanistycznego charakteru?

„Antyhumanizm pana i władcy” to głębokie przeświadczenie o odkryciu "prawdy” o człowieku jako w pełni (słowo „pełnia” jest tutaj kluczowe) racjonalnym, samoświadomym i autonomicznym podmiocie i wynikające $z$ tego podporządkowanie mu całej rzeczywistości. To unoszące się nad takim myśleniem przekonanie, że świat został ostatecznie zrozumiany, że - podobnie jak człowiek nie skrywa już żadnej tajemnicy. „Antyhumanizm zluzowanego” to z kolei całkowita rezygnacja z myślenia w kategoriach "prawdy”, to uczynienie człowieka nieokreślonym i niedefiniowalnym, podobnie jak nieokreślona i niedefiniowalna jest cała rzeczywistość. Antyhumanistyczne było oświeceniowe przeszacowanie człowieka, ale antyhumanistyczna jest także ponowoczesna jego nieokreśloność. 
Antyhumanistyczne było uczynienie człowieka demiurgiem, ale antyhumanistyczne jest czynienie go „niczym”, by w ten sposób wracając do słów Sartre’a - mógł stać się wszystkim.

Czy nie takie jest właśnie podglebie współczesnej humanistycznej kultury? Czy jeśli u jej podstaw leży ostatecznie zafałszowane rozumienie człowieka, to wciąż mamy do czynienia $\mathrm{z}$ humanizmem? A może jest wprost przeciwnie? Czy to jednak oznacza, że kwestionuje się na przykład godność człowieka i przeświadczenie, że wszystko powinno być podporządkowane indywidualnemu dobru jednostki? Bynajmniej. Problem polega jednak na tym, że w ramach takiego myślenia następuje istotne przesunięcie rozumienia godności z poziomu natury na poziom dyskursów, języka, wartości, kreacji, wytwarzania, stawania się. $Z$ poziomu ,przyrodzoności” na poziom „nieokreśloności”. Nieokreśloności, która domaga się - oczywiście w ramach niczym nieograniczonej wolności - nieustannego określania. Określania, które - co niezwykle istotne - także w ramach niczym nieograniczonej wolności - nie może być przez cokolwiek i kogokolwiek narzucane. Ludzka godność nie ma więc podstawy w naturze człowieka, bo takiej natury po prostu nie ma. Ludzka godność jest wytwarzana, staje się, podobnie jak staje się sam człowiek. Czy to jednak wciąż jeszcze humanizm?

\section{PODMIOT ŚWIADOMY SWOJEJ NIEMOCY - W POSZUKIWANIU TRZECIEJ DROGI}

Opisane powyżej rozumienia zostały zbudowane na niezwykle prostej opozycji - wszystko albo nic. Ponieważ nieprawdą jest, że podmiot jest dla siebie całkowicie racjonalny, przejrzysty i jest autonomicznym panem samego siebie, musi zniknąć, trzeba o nim zapomnieć. Renaut pisze o tym w następujący sposób: „proces wytaczany idei podmiotu co najmniej od czasów Nietzschego czy Heideggera i, zupełnie niedawno przez »myśl 68«, rozwinął się w oparciu o wyjątkowo upraszczające podstawy, jak gdyby każde użycie pojęcia 
podmiotowości musiało nieuchronnie pociągać za sobą temat podmiotu w całości przejrzystego dla samego siebie, suwerena, władcy siebie i wszechświata, i jak gdyby wynikające stąd niezaprzeczalne wyjałowienie tej postaci podmiotu zmuszało do całkowitego porzucenia jakiegokolwiek odniesienia do podmiotowości”69. Jeśli tak, zasadne staje się pytanie, czy nie ma innego wyjścia, czy jesteśmy skazani na taką właśnie alternatywę? Czy w myśleniu o człowieku jako podmiocie mamy do dyspozycji jedynie dwie drogi: jego deifikację albo anihilację?

Wydaje się, że pomiędzy podmiotem absolutnym a podmiotem, do którego trzeba zaprzestać się odnosić, jest jeszcze cała przestrzeń realistycznego spojrzenia na podmiot, realistycznego odczytania tego co ludzkie, humanistyczne. Chantal Delsol w duchu takiego właśnie sposobu myślenia w Eseju o cztowieku późnej norwoczesności używa bardzo wymownego obrazu, mówi o „ranie skończoności”. Tłumaczy, że oświeceniowy podmiot przekonany o swojej absolutnej mocy i samowystarczalności ostatecznie zrodził barbarzyństwo i totalitaryzmy. Stało się tak dlatego, że zanegował swoją skończoność, ułomność i niedoskonałość, że w swojej wyniosłości przypisał sobie atrybuty, których w rzeczywistości nie posiada. Tymczasem prawdziwa ludzka kultura i humanizm rodzą się z doświadczenia - bolesnego, ale jakże prawdziwego - związanego z naszą skończonością i ograniczonością, z tego głębokiego przekonania, że człowiek nie jest wcale samowystarczalny, że nie jest absolutem ${ }^{70}$. Delsol pisze: „Godność osoby wyrasta właśnie z rany skończoności. Człowiek jest wielki nie dlatego, że mógłby rozwiązać swoje problemy, ale dlatego, że z nimi się boryka. Jest wielki w tym tragizmie, przez tę uświadomioną skończoność, odróżniającą go od zwierząt, które pozostają w podwójnej niewiedzy: nie wiedzą, że nie wiedzą"71.

69 A. Renaut, Era jednostki, dz. cyt., 17.

70 Zob. C. Delsol, Esej o człowieku, dz. cyt., 65-78.

71 Tamże, 72. 
Uświadomienie sobie tej prawdy jest niezwykle istotne. Tylko tak bowiem można ochronić wyjątkowość i wielkość człowieka, których bynajmniej nie niszczy jego skończoność i niewystarczalność. One, jak rana właśnie, nieustannie przypominają, kim jesteśmy, jakie są nasze możliwości, ale także jakie są nasze ograniczenia. Ograniczenia, o których oświeceniowy podmiot w swojej zuchwałości chciał całkowicie zapomnieć. Delsol tłumaczy: „Wynalezienie podmiotu było piękną przygodą, którą zrujnowała nowoczesna pycha. Nowoczesny podmiot uznał się za demiurga. Obdarzony autonomią, czyli zdolnością do nadawania sobie praw, sądził, że jest niezależny od wszelkiego prawa. Jako podmiot utracił wcześniejsze pewniki i dotychczasowe schronienie i stanął oko w oko ze sprzecznościami egzystencji. Wykorzystał swoją władzę, aby próbować te sprzeczności usunąć, co okazało się porażką. Ponieważ nie udało mu się stworzyć siebie od nowa, woli dzisiaj negować własną podmiotowość"72.

Wydaje się, że naturę tak opisanego mechanizmu odnajdujemy jednak nie tylko w oświeceniu. O ludzkich ograniczeniach, o tej „ranie skończoności” nie chce pamiętać także człowiek ponowoczesny. Również i w tym przypadku mamy do czynienia ze szczególnym rodzajem „nowoczesnej pychy”, z próbą „stworzenia człowieka od nowa”. Czy negacja wszelkiej uniwersalności, myślenia o wspólnej wszystkim racjonalnej naturze, o konkretnej koncepcji człowieka nie jest podszyta takim właśnie myśleniem? Bez wątpienia. Również tutaj człowiek nie akceptuje tego, że jest jakiś, że jest określony, ukonstytuowany, zdefiniowany, że nie jest absolutem, że nie może wszystkiego. Delsol pisze: „Współczesny świat wspólny jest rozbijany nie przez gwałtowne walki między rozbieżnymi odpowiedziami, jak działo się to niegdyś przy okazji wojen religijnych, ale przez wycofanie się każdej jednostki poza obszar kulturowych odpowiedzi na pytanie odsłaniające istotę człowieczeństwa, a nawet, głębiej, przez jej wycofanie się poza zasięg samego pytania. (...) Człowiek późnej

72 Tamże, 93-94. 
nowoczesności porzuca swój świat kulturowy, ponieważ sądzi, że jest niezależny, że nic nikomu nie jest winien, że nie dotyczą go odziedziczone długi. Pełna pychy wiara w samowystarczalność nie pozwala mu stworzyć żadnego wspólnego świata, bo taki świat można zorganizować tylko wokół uświadomionej skończoności własnego bytu. Mogę bronić postulatów wspólnej kultury tylko wtedy, gdy akceptuję zawsze niepewny charakter ludzkich prawd. Bo celem tych postulatów nie jest uchronienie mnie od niepokoju, ale uczynienie go znaczącym. Mogę dawać i otrzymywać tylko wtedy, gdy znam swoje braki. Mogę wybaczać tylko wtedy, gdy sam czuję się zdolny do zła. Współczesna jednostka nie daje ani nie przebacza, nie uznaje żadnej wspólnej prawdy, ponieważ sądzi, że znajduje się w sytuacji autarkii"73.

Współczesny człowiek nie potrzebuje więc niczego poza sobą. W swojej pysznej niezależności, samowystarczalności, w tym „nieuznawaniu żadnej wspólnej prawdy" nie chce zaakceptować swojej ludzkiej kondycji, nie chce zgodzić się na swoją ograniczoność i skończoność. Czy nie dlatego porzuca myślenie w kategoriach istoty, natury człowieka? Czy nie dlatego, podkreślając - jako najbardziej ludzką działalność - dążenie do wewnętrznej autonomii, wolności i prawa do wyrażania swej odmienności, indywidualności, kwestionuje istnienie jakichś metafizycznych niezmienników czy choćby trwałej tożsamości i patrzy na człowieka jak na twór okoliczności kulturowych i historycznych, jak na rezultat oddziałujących na niego dyskursów czy gier językowych?74 $\mathrm{W}$ ten sposób jednak, w imię absolutnej wolności i prawdziwego (chciałoby się powiedzieć wreszcie) humanizmu, serwuje sobie $\mathrm{w}$ gruncie rzeczy antyhumanistyczną „autarkię". Antyhumanistyczną, bo odnoszącą nas do próżni i pustki.

Co może nas przed nią ochronić? Realizm. Ta boleśnie realistyczna, ale jednocześnie wyzwalająca z pokusy stania się jak Bóg,

73 Tamże, 69.

74 Zob. A. Szachaj, Co to jest postmodernizm?, Ethos 1-2(1996)33-34, 75. 
„rana skończoności”. Ostatnie wieki wyraźnie o tym zapomniały. W ten sposób w imię absolutyzacji rozumu człowiek jako nowożytny podmiot stał się demiurgiem, a w imię absolutyzacji wolności - nieokreślonością. A przecież między prawdą, którą człowiek wytwarza, a prawdą, której nie ma lub która nie ma znaczenia, jest wciąż miejsce na prawdę, której człowiek wciąż poszukuje. Delsol pisze: „Właściwością człowieka jest pragnienie prawdy, której nigdy nie osiąga w stopniu doskonałym, dlatego jest prawdziwie sobą tylko w tym gorączkowym poszukiwaniu”75. I dodaje: „Ocalić podmiot znaczyłoby ocalić poszukiwanie prawdy"76.

Może zatem istnieje trzecia droga? Jeśli Delsol ma rację, mówiąc, że „nowoczesny podmiot jeszcze się nie narodził"77, to droga do jego narodzin bez wątpienia prowadzi przez „poszukiwanie prawdy”, zwrócenie się w stronę owej „rany skończoności”. Rany, która mimo najróżniejszych zabiegów nigdy się nie zagoi, która wciąż będzie otwarta, która jak stygmat przypominać będzie o naszej ludzkiej kondycji, o naszej skończoności i niewystarczalności. Tylko tak można zbudować prawdziwie humanistyczną kulturę.

\section{ZAKOŃCZENIE}

Przedstawione powyżej analizy ukazują, że zarówno nowoczesność, jak i ponowoczesność zostały zbudowane - mówiąc oczywiście w wielkim uproszczeniu - na pewnych zafałszowanych, nierealistycznych wizjach człowieka. Nierealistyczne było uczynienie człowieka „panem i władcą", ale nierealistyczne jest także czynienie go „niczym”, nawet jeśli to „nic” miałoby stać się wszystkim. W jednym i drugim przypadku mamy do czynienia z pewnym rodzajem antyhumanizmu. "Antyhumanizmu pana i władcy” i , antyhumanizmu zluzowanego”,

75 C. Delsol, Esej o człowieku, dz. cyt., 111.

76 Tamże.

77 Tamże, 96. 
które mają swoje źródło nie tyle w chęci wywyższenia człowieka, podkreślenia jego wyjątkowości, ale raczej w zamiarze jego ubóstwienia, zabsolutyzowania. Tak było wtedy, gdy człowiek rodził się jako podmiot, gdy stawał się ostatecznym podłożem rzeczywistości, ale tak było również, kiedy „znikał”, stając się bytową nieokreślonością.

Te dwie wizje - stojąc u spodu współczesnej, wydawałoby się humanistycznej kultury - sprawiają, że ta kultura nabiera wyraźnie antyhumanistycznych rysów. W związku z tym nasuwa się pytanie, czy między podmiotem absolutnym a bytową nieokreślonością jest miejsce na realistyczne, niezafałszowane spojrzenie na człowieka? Bez wątpienia. Takiego właśnie rozumienia współczesny świat potrzebuje. Tylko tak można ten świat ocalić. Tylko tak można ocalić człowieka. Ocalić to znaczy, wracając do słów Delsol, nieustannie poszukiwać prawdy o nim - prawdy, której nie tworzymy, lecz odkrywamy. To znaczy przestać człowieka absolutyzować, ale przestać również pozbawiać go pewnej bytowej swoistości, pewnego wyróżnionego sposobu istnienia. Współczesna refleksja filozoficzna, stając wobec takich zjawisk, jak posthumanizm, transhumanizm, nowy materializm czy wszelkiego rodzaju antyhumanizmy, potrzebuje więc pogłębionego - rozumiejącego historię, ale i wyciągającego $\mathrm{z}$ niej wnioski - namysłu nad człowiekiem. Namysłu, który - wolny od takich czy innych ideologii - dostrzegał będzie wyjątkowość i wielkość człowieka, ale także jego ograniczoność i niewystarczalność, które wcale tej wyjątkowości i wielkości nie podważają.

\section{BIBLIOGRAFIA}

Arystoteles, Metafizyka, I, tłum. z grec. T. Żeleźnik, TN KUL, Lublin 2000. Banasiak B., I cóż po podmiocie w tak jatowym czasie? Przyczynek do krytyki kategorii podmiotu, Forum Oświatowe 20(2008), 27-38, http://forumoswiatowe.pl/index. php/czasopismo/article/view/248/163 (dostęp: 8.07.2017).

Cassirer E., Filozofia oświecenia, tłum. z niem. T. Zatorski, Wydawnictwo Uniwersytetu Warszawskiego, Warszawa 2010. 
Czarnecki Z.J., Idea podmiotowości człowieka w myśli antycznej, w: Studia nad ideq podmiotowości cztowieka, red. Z.J. Czarnecki, Wydawnictwo Uniwersytetu Marii Curie-Skłodowskiej, Lublin 1999, 43-62.

Delsol C., Esej o cztowieku późnej nowoczesności, tłum. z fr. M. Kowalska, Wydawnictwo ZNAK, Kraków 2003.

Derrida J., Kres cztowieka, tłum. z fr. P. Pieniążek, w: tenże, Marginesy filozofii, tłum. z fr. A Dziadek, J. Margański, P. Pieniążek, Warszawa 2002, 151-182.

Derrida J., Marginesy filozofi, tłum. z fr. A Dziadek, J. Margański, P. Pieniążek, Warszawa 2002.

Derrida J., Pismo i różnica, tłum. z fr. K. Kłosiński, Wydawnictwo KR, Warszawa 2004.

Derrida J., Struktura, znaki gra w dyskursie nauk humanistycznych, w: tenże, Pismo i różnica, tłum. z fr. K. Kłosiński, Wydawnictwo KR, Warszawa 2004, 483-504.

Derridiana, red. B. Banasiak, Inter esse, Kraków 1994.

Descombes V., To samo i inne. Czterdzieści pięć lat filozofi francuskiej (1933-1978), tłum. z fr. B. Banasiak, K. Matuszewski, Wydawnictwo SPACJA, Warszawa 1997.

De Waelhens A., Heidegger i problem podmiotu, tłum. z fr. M. Kowalska, w: Heidegger dzisiaj, Aletheia 1(1991)4, 181-188.

Foucault M., Stowa i rzeczy. Archeologia nauk humanistycznych, tlum. z fr. T. Komendant, słowo/obraz terytoria, Gdańsk 2006.

Gadamer H.G., Rozum, stowo, dzieje, tłum. z niem. M. Łukasiewicz, K. Michalski, Państwowy Instytut Wydawniczy, Warszawa 2000.

Gloy K., Wprowadzenie do filozofii świadomości. Problematyka i historia zagadnienia świadomości oraz samoświadomości, tłum. z niem. T. Kubalica, Wydawnictwo WAM, Kraków 2009.

Gra resztkami. Wywiad z Jeanem Baudrillardem przeprowadzony przez Salvatore Mele i Marka Titmarsha, tłum. z ang. A. Szachaj, w: Postmodernizm a filozofia. Wybór tekstów, red. S. Czerniak, A. Szachaj, Instytut Filozofii i Socjologii PAN, Warszawa 1996, 203-228.

Gurczyńska-Sady K., Cztowiek jako stowo i ciato. W poszukiwaniu nowej koncepcji podmiotu, Universitas, Kraków 2013.

Hegel G.W.F., Encyklopedia naukfilozoficznych, tłum. z niem. Ś.F. Nowicki, Wydawnictwo Naukowe PWN SA, Warszawa 2014.

Heidegger dzisiaj, Aletheia 1(1991)4.

Heidegger M., Budować, mieszkać, myśleć. Eseje wybrane, tłum. z niem. K. Michalski, K. Pomian, M. J. Siemek, J. Tischner, K. Wolicki, Czytelnik, Warszawa 1977. 
Heidegger M., List o humanizmie, tłum. z niem. J. Tischner, w: tenże, Budować, mieszkać, myśleć. Eseje wybrane, tłum. K. Michalski, K. Pomian, M.J Siemek, J. Tischner, K. Wolicki, Czytelnik, Warszawa 1977, 76-127.

Kant I., Rozprawy z filozofii historii, tłum. z niem. Translatorium filozofii niemieckiej Instytutu Filozofii Uniwersytetu im. Mikołaja Kopernika pod kierunkiem M. Żelaznego w składzie: T. Kupiś, D. Pakalski, A. Grzeliński, M. Żelazny, Wydawnictwo ANTYK, Kęty 2005.

Kitliński T., Między tożsamościq a różNICą: podmiot w procesie, w: Studia nad idea podmiotowości cztowieka, red. Z.J. Czarnecki, Wydawnictwo Uniwersytetu Marii Curie-Skłodowskiej, Lublin 1999, 223-242.

Lorenc W., Hegel i Derrida. Filozofia w wersji radykalnej, Uniwersytet Warszawski. Instytut Filozofii, Warszawa 1994.

Miś A., O genezie wspótczesnego humanizmu, w: Derridiana, red. B. Banasiak, Inter esse, Kraków 1994, 21-56.

Miś A., Filozofia Wspótczesna. Gtówne nurty, Wydawnictwo Naukowe SCHOLAR, Warszawa 2002.

Niemczuk A., Między bytem a wartościq: problem podmiotu, w: Studia nad ideq podmiotowości cztowieka, red. Z.J. Czarnecki, Wydawnictwo Uniwersytetu Marii Curie-Skłodowskiej, Lublin 1999, 11-42.

Nietzsche F., Pisma pozostate, tłum. z niem. B. Baran, Inter Esse, Kraków 2004. Nietzsche F., Zmierzch bożyszczy, czyli jak filozofuje sie mtotem, tłum. z niem. P. Pieniążek, Wydawnictwo Zielona Sowa, Kraków 2005.

Nowak A.W., Podmiot, system, nowoczesność, Wydawnictwo Naukowe Instytutu Filozofii Uniwersytetu im. Adama Mickiewicza w Poznaniu, Poznań 2011.

Nowicki Ś.F., Filozofia Hegla jako spekulatywny system, w: G.W.F. Hegel, Encyklopedia nauk filozoficznych, tłum. Ś.F. Nowicki, Wydawnictwo Naukowe PWN SA, Warszawa 2014, XI-LXXXIV.

Powszechna Encyklopedia Filozofii, t. IX, Polskie Towarzystwo Tomasza z Akwinu, Lublin 2008.

Postmodernizm a flozofia. Wybór tekstów, red. S. Czerniak, A. Szachaj, Instytut Filozofii i Socjologii PAN, Warszawa 1996.

Renaut A., Era jednostki. Przyczynek do historii podmiotowości, tłum. D. Leszczyński, Zakład Narodowy im. Ossolińskich, Wrocław - Warszawa - Kraków 2001, 31-32.

Sartre J.P., Byt i nicość. Zarys ontologii fenomenologicznej, tłum. z fr. J. Kiełbasa, P. Mróz, A. Abramciów, R. Ryziński, P. Małochleb, Wydawnictwo Zielona Sowa, Kraków 2007. 
Sartre J.P., Egzystencjalizm jest humanizmem, tłum. z fr. J. Krajewski, Warszawskie Wydawnictwo Literackie MUZA, Warszawa 1998.

Siemek M., Wyktady z filozofii nowoczesności, Wydawnictwo Naukowe PWN, Warszawa 2012.

Studia nad idea podmiotowości cztowieka, red. Z.J. Czarnecki, Wydawnictwo Uniwersytetu Marii Curie-Skłodowskiej, Lublin 1999.

Szachaj A., Co to jest postmodernizm?, Ethos 33-34(1996)1-2, 63-78.

Taylor C., Źródta podmiotowości. Narodziny tożsamości nowoczesnej, tłum. z ang. M. Gruszczyński, O. Latek, A. Lipszyc, A. Michalak, A. Rostkowska, M. Rychter, Ł. Sommer, Wydawnictwo Naukowe PWN, Warszawa 2012.

\section{BETWEEN AN ABSOLUTE SUBJECT AND AN INDEFINITE BEING. ABOUT ANTI- HUMANISTIC SOURCES OF CONTEMPORARY CULTURE}

Abstract. This paper is an attempt to identify the sources of contemporary culture. The author argues that at its bottom we can find a form of antihuman thinking. Such thinking derives from the perspective of „the death of a man”, his indefinite being, but also from the perspective of the modern cogito, the absolutized subject who becomes a special kind of foundation, the ultimate subject of reality.

In the first part of the paper, the author describes in detail the contemporary understanding of human being, according to which man as a thinking, cognizing, self-aware, and rational subject assigns himself the role of a modern sovereign, a Demiurge, the only legislator and architect of a new, truly human world. In accordance with the meaning of the word "subject", man thus becomes the "ultimate foundation" of reality.

In the second part of the paper, however, the author argues that the absolutization of the subject, which assigns him more and more powers, leads to his undermining and negation. Taking into account the views of philosophers such as Nietzsche, Heidegger, Sartre, Foucault, and Derrida, he shows that the negation of the Cartesian cogito, or the "death" of a specific vision of man as a subject, leads to the thought that man becomes an indefinite being.

In the third part of the paper, the author explains that both modern and post-modern thinking are influenced by antihuman thinking, which in both cases results in an unrealistic view of human beings. The author speaks of the "antihumanism of Lord and master", and „antihumanism of the loosened up" and argues that these are the bedrock of modern humanism.

Lastly, the author shows that the understanding of the role of the subject during the last centuries was built on a very simple opposition - everything or nothing. Since it is not true that the subject is completely rational, transparent, and that he is an autonomous master of himself, he must disappear, he must be forgotten. Hence, the idea of "man's death". 
In this context, taking into account the intuition of the French philosopher Chantal Delsol, the author attempts to break out the aporia between a modern, absolute, and self-sufficient subject, and a postmodern subject that does not actually exist. The author expresses the need for a realistic view of man as the only way to establish a truly humanistic culture.

Keywords: subject, man as a subject, „death of man”, modernity, postmodernity, antihumanism, Nietzsche, Heidegger, Sartre, Foucault, Derrida, Delsol, realism

SYLWESTER WARZYŃSKI

sylwester.w@ukw.edu.pl

Uniwersytet Kazimierza Wielkiego w Bydgoszczy, Instytut Filozofii

Ogińskiego 16, 85-092 Bydgoszcz

ORCID: 0000-0002-1333-2552

DOI: 10.21697/spch.2020.56.1.05 